\title{
Role of nuclear factor kappa beta, tumor necrosis factor $\alpha$, and cyclooxygenase- 2 in preterm labor
}

\author{
Syamsul B. Riva'i, ${ }^{1}$ Eryati Darwin, ${ }^{2}$ Ellyza Nasrul, ${ }^{3}$ Jusuf S. Effendi ${ }^{4}$ \\ ${ }^{1}$ Department of Obstetrics and Gynecology, Arifin Achmad Regional Hospital, Riau University, Indonesia \\ ${ }^{2}$ Department of Pathology Anatomy, Andalas University, Padang, Indonesia \\ ${ }^{3}$ Department of Clinical Pathology, Andalas University, Padang, Indonesia \\ ${ }^{4}$ Department of Obstetrics and Gynecology, Padjadjaran University, Bandung, Indonesia
}

\begin{abstract}
Abstrak
Latar belakang: Jalur aktivasi tumor necrosis factor alpha $(\mathrm{TNF} \alpha)$, nuclear factor $\kappa \mathrm{B}(\mathrm{NF}-\kappa \mathrm{B})$ dan cyclooxygenase-2 (COX-2) dalam melepaskan prostaglandin merupakan hal penting dalam proses persalinan sebagai patogenesis persalinan prematur. Penelitian ini bertujuan membandingkan perbedaan rerata ekspresi $T N F \alpha, N F-\kappa B$ dan $C O X-2$ antara persalinan prematur dengan persalinan normal serta mengetahui korelasi antara ekspresi $N F-\kappa B$, $T N F \alpha$ dan $C O X-2$ dalam persalinan prematur.
\end{abstract}

Metode: Studi kasus-kontrol dilakukan di RS Arifin Achmad, Pekanbaru sejak Mei 2013 hingga Februari 2014. Sebanyak 30 pasien dengan persalinan prematur sebagai kasus dan 30 pasien dengan persalinan normal sebagai kontrol. Seluruh subjek mempunyai paritas maksimal 3 orang, dengan batasan umur 35 tahun, dan persalinan spontan pada kedua kelompok. Jaringan plasenta diperoleh dari seluruh subjek dan dilakukan pewarnaan hematoksilin eosin. Ekspresi $T N F \alpha, N F-\kappa B$, dan $C O X-2$ dalam jaringan tersebut dinilai dengan pewarnaan imunohistokimia dengan menghitung persentasi sel yang terwarnai oleh dua ahli. Ekspresi TNF $\alpha, N F-\kappa B$, dan COX-2 antara kelompok dan kontrol dibandingkan menggunakan uji-t dan korelasi diselidiki dengan koefisien korelasi Pearson.

Hasil: Rerata (SD) ekspresi TNFa $(93,05 \%$ [12,68] banding 49,11\% [27,33]), NF- $\kappa B \quad(42,46 \% \quad[27,29]$ banding 13,66\% [17,77]), dan COX-2 (88,75\% [10,86] banding 46\% [30,36]) lebih tinggi secara bermakna pada persalinan prematur dibanding persalinan matur. Selain itu, terdapat korelasi yang bermakna antara ekspresi $T N F \alpha$ dan $N F-\kappa B$ pada persalinan prematur $(r=0,385 ; p$ $=0,036)$, dan tidak ditemukan korelasi antara $N F-\kappa B$ dan COX-2 $(p=0,982)$.

Kesimpulan: Tingginya ekspresi TNF $\alpha, N F-\kappa B$, dan COX-2 pada kelompok persalinan prematur menunjukkan perannya terhadap terjadinya persalinan prematur. Tingginya ekspresi TNFa menunjukan bahwa infeksi merupakan penyebab tertinggi persalinan prematur. Hal ini dibuktikan dengan peningkatan aktivasi $N F-k B$ akan meningkatkan COX-2 dan kemudian meningkatkan prostaglandin sehingga terjadi persalinan prematur.

\begin{abstract}
Background: The pathway of tumor necrosis factor alpha $(\mathrm{TNF} \alpha)$, nuclear factor kappa beta $(\mathrm{NF}-\kappa \mathrm{B})$, and cyclooxygenase-2 (COX-2) activation in releasing prostaglandins is suggested to be crucial for initiating labor in the pathogenesis of preterm labor. The aim of the study was to know whether there were mean differences of NF$\kappa \mathrm{B}, \mathrm{TNF} \alpha$, and $\mathrm{COX}-2$ expressions between preterm and term labor and also to know the correlation among them in preterm labor.
\end{abstract}

Methods: A case-control study was performed from May 2013 to February 2014 in Arifin Achmad Hospital, Pekanbaru. There were 30 subjects with preterm labor as cases and 30 with normal labor as controls. All subjects had singleton gestation with maximum parity was three, age limit of 35 year-old, and spontaneous labor in both groups. Placental tissue was collected from all subjects and evaluated with hematoxylin eosin staining. The expressions of $\mathrm{TNF} \alpha, \mathrm{NF}-\kappa \mathrm{B}$, and $\mathrm{COX}-2$ in the tissue were assessed with immunohistochemical staining by counting the percentage of smeared cells by two experts. The expressions of TNF $\alpha, N F-\kappa B$, and COX-2 between case and control were compared using t-test and the correlation was analyzed with Pearson correlation coefficient.

Results: Mean (SD) of expressions of TNF $\alpha(93.05 \%$ [12.68] vs 49.11\% [27.33]), NF- $\mathrm{BB}(42.46 \%$ [27.29] vs $13.66 \%$ [17.77]), and COX-2 (88.75\% [10.86] vs $46 \%$ [30.36]) were significantly higher in the preterm labor compared to term labor $(\mathrm{p}=0.001)$. There was significant correlation between TNF $\alpha$ and NF- $\kappa \mathrm{B}$ expression $(\mathrm{r}=$ $0.385 ; \mathrm{p}=0.036)$ and no correlation was found between $\mathrm{NF}-\kappa \mathrm{B}$ and COX-2 $(\mathrm{p}=0.982)$ in preterm labor.

Conclusion: High expressions of $\mathrm{TNF} \alpha, \mathrm{NF}-\kappa \mathrm{B}$, and COX-2 in preterm labor showed to contribute in the onset of preterm labor. High TNF $\alpha$ may suggest that infection was a leading cause of preterm labor. This is supported with an increase in NF- $\kappa \mathrm{B}$ activation will increase COX-2 and subsequently prostaglandins that result in premature labor.

Keywords: COX-2, NF- $\mathrm{KB}, \mathrm{TNFa}$, preterm labor 
Preterm birth is a major problem for the welfare of infants due to the immaturity of organ systems which may lead to numerous complications in preterm babies. It is estimated that 15 million babies were born preterm annually worldwide and out of which one million died because of related complications. ${ }^{1,2}$ World Health Organization (WHO) defines preterm birth as any birth before 37 completed weeks of gestation. ${ }^{3}$ Preterm labor can occur spontaneously or be initiated by health provider based on some indications, i.e.: placenta previa, pre-eclampsia, and multiple gestation. About $70 \%$ of preterm labors happened spontaneously and they were caused mainly by infection followed with idiopathic spontaneous preterm labor. ${ }^{4,5}$

Based on the pathogenesis, preterm labor may be initiated by activation of the hypothalamus-pituitaryadrenal axis or neurohormonal changes in the mother or fetus. Physical or psychological stress will stimulate production of estrogen and corticotrophinreleasing hormone by placenta, which subsequently activates the decidua and amniotic membrane to release prostaglandin, resulting in triggering contractions. $^{6}$ Other suggested pathogenesis include decidual bleeding, decidual-chorioamniotic inflammation, hormonal, enzymatic, biochemical and genetic changes leading to uterine contraction, cervical changes and rupture of membranes. ${ }^{5,7}$

It has been hypothesized that the triggering factor of preterm labor is an increase activation of nuclear factor kappa beta (NF- $\mathrm{kB})$. NF- $\mathrm{\kappa B}$ is a protein complex controlling DNA transcription which is activated as a response to infection and inflammatory cytokines. ${ }^{8}$ One of the cytokines acting as stimuli in activating NF- $\kappa \mathrm{B}$ is tumor necrosis factor alpha $(\mathrm{TNF} \alpha)$. The augmented NF- $\mathrm{KB}$ activity will increase cyclooxygenase-2 (COX-2) activation, which in turn will elevate prostaglandin release through arachidonic acid conversion. Increase of prostaglandin will lead more cervical collagen breakdown as well as estrogen and oxytocin release resulting in uterine contraction, cervix dilatation, and rupture of membranes with consequent preterm labor. ${ }^{9}$

Therefore, there should be correlations between $\mathrm{TNF} \alpha, \mathrm{NF}-\kappa \mathrm{B}$, and COX-2 expressions in preterm labor. To understand the pathogenesis and prevention of preterm labor, the molecular mechanism of preterm labor needs to be investigated. This study was aimed to compare mean of expression of NF- $\kappa \mathrm{B}, \mathrm{TNF} \alpha$, and COX-2 between preterm labor and term labor and to correlate the expressions among them in preterm labor.

\section{METHODS}

A case-control study was performed in Department of Obstetrics and Gynecology of Arifin Achmad Hospital, Pekanbaru. All subjects were taken consecutively from May 2013 to February 2014 based on inclusion and exclusion criteria. Based on previous calculation, 30 subjects were needed for each group. Ethical clearance was obtained from the Research Ethics Committee of the Faculty of Medicine Andalas University and all patients signed informed consent form.

We included patients aged up to 35 year-old of parity maximum three and had uncomplicated singleton gestations. Subjects were included in case group if they presented with spontaneous preterm labor which was defined as 20- to 36-week gestational age with vaginal delivery. The control group comprised of subjects who had normal spontaneous labor. Patients were excluded if they refused to be involved in the study or admitted smoking, consumed alcohol, or used illicit drug.

Leucocyte was checked when the patient came to the hospital. Gestational age was calculated from last menstrual period reported by patients or from reliable medical records.

A $2 \times 2 \times 2 \mathrm{~cm}^{3}$ sample of placenta tissue from each subject was obtained immediately after the placenta had delivered or during the fourth stage of labor. The collected tissue was then preserved in $10 \%$ formaldehyde solution and kept in a labeled container in room temperature before being sent to the Department of Anatomical Pathology of Arifin Achmad Hospital for histopathological and immunohistochemical (IHC) assessment. Sample preparation, staining, and assessment were performed by trained pathologists and anatomical pathologists of Arifin Achmad Hospital. Collected tissues were stained with hematoxylin eosin for histopathological examination to evaluate morphology of cytotrophoblast, syncytiotrophoblast, and blood vessels in the chorionic villi. Subsequently, IHC staining was employed and the intensity of staining was evaluated using breast cancer tissue as positive control because the immunologic reactions (TNF $\alpha, N F-\kappa B$ and COX-2) of breast cancer are the same as in placental tissue. 
Evaluation of NF- $\kappa$ B was done using anti-NF- $\kappa$ B p 65 antibody-ChIP Grade kit from Abcam (Cambridge, UK), besides TNF $\alpha$ and COX-2 were stained using staining kits for polyclonal anti-TNF $\alpha$ and antiCOX-2 from anti-rabbit IgG. The IHC staining was assessed under microscope camera from Leica with 400x magnification in 10 microscopic fields. The assessment was performed by two anatomical pathologists and we used the average of both assessments.

Expressions of $\mathrm{TNF} \alpha, \mathrm{NF}-\kappa \mathrm{B}$, and $\mathrm{COX}-2$ were examined by counting the number of cells of which the cytoplasm and nuclei were smeared. Hence, the expressions were analyzed in term of percentage in numerical variable. We used statistical analysis of T-test to know mean difference between case and control groups and Pearson correlation test using the Statistical Package for the Social Sciences (SPSS 17) for Windows.

\section{RESULTS}

From May 2013 to February 2014, we enrolled 60 patients in our study, consisted of 30 cases and 30 controls. The characteristics of both groups are presented below in table 1 .

Mean of gestational age in case group was 31.1 (4.0) weeks. Half of subjects $(n=15)$ in case group belonged to late preterm, with gestational age of 33 to 36 week. Eight subjects $(27 \%)$ were at gestational age of 29 to 32 weeks and the others $(23 \%)$ were at 20 to 28 week of gestational age.

Based on our observation, IHC staining of cytotrophoblasts was intensified in the preterm labor group compared to control, indicating increase of expression of TNF $\alpha, N F-\kappa B$, and COX-2 in the case group. The difference of IHC intensity is illustrated in figure 1.

Table 2 shows the mean of TNF $\alpha, N F-\kappa B$, and COX-2 expression in case (preterm labor) and control (normal)

Table 1. Characteristics of subjects in preterm labor (case) and normal labor (control)

\begin{tabular}{lcc}
\hline \multirow{2}{*}{ Variable } & \multicolumn{2}{c}{ Mean $(\mathrm{SD})$} \\
\cline { 2 - 3 } & preterm $(\mathrm{n}=30)$ & normal $(\mathrm{n}=30)$ \\
\hline Maternal age (years) & $24.9(4.9)$ & $26.4(5.4)$ \\
Parity & $1.6(0.8)$ & $1.5(0.7)$ \\
Leukocytes $\left(/ \mathrm{mm}^{3}\right)$ & $16,906(5,989)$ & $12,283(3,422)$ \\
\hline
\end{tabular}

group. The expressions were higher in the case group compred to control group. Mean of TNF $\alpha$ was increased almost two-fold in preterm labor. Moreover, mean of NF- $\mathrm{kB}$ expression was significantly different between two groups. The preterm group found to be more than three-fold in the term labor group. Mean of COX-2 expression in the case group was almost twice of mean in control group.

Table 2. Mean of TNF $\alpha, N F-\kappa B$, and COX-2 expressions in both groups

\begin{tabular}{lccc}
\hline \multirow{2}{*}{ Measurement } & \multicolumn{2}{c}{ Mean (SD) \% } & \multirow{2}{*}{$\mathrm{p}^{*}$} \\
\cline { 2 - 3 } & Preterm labor & Normal & \\
\hline TNF $\alpha$ & $93.05(12.68)$ & $49.11(27.33)$ & $0.001^{*}$ \\
NF-אB & $42.46(27.29)$ & $13.66(17.77)$ & $0.001^{*}$ \\
COX-2 & $88.75(10.86)$ & $46(30.36)$ & $0.001^{*}$ \\
\hline
\end{tabular}

*statistically significant

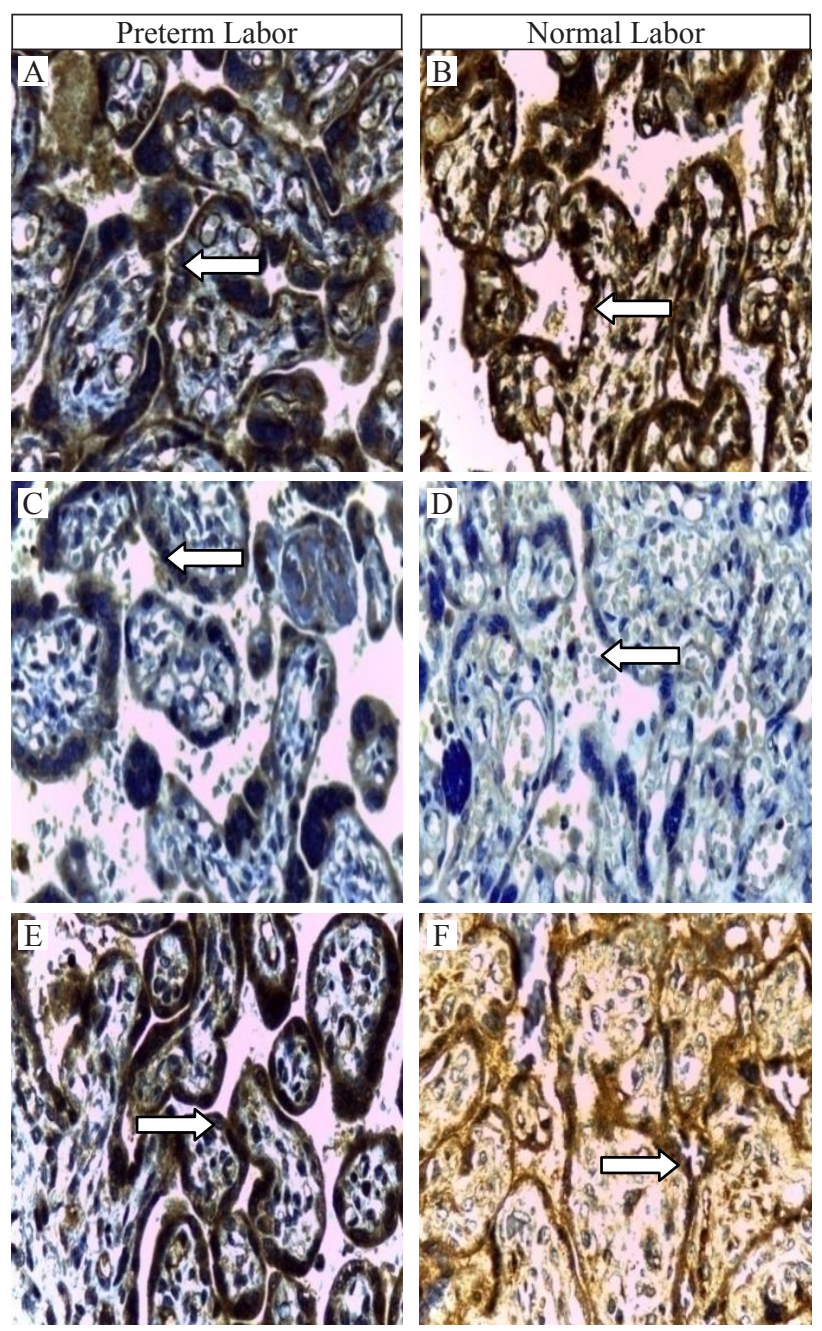

Figure 1. Microscopic view (x400) of IHC staining of placental tissue. Observation of TNF $\alpha$ (A and B), NF-kB (C and D), and COX-2 (E and F) in case and control groups. The arrows show cytotrophoblasts with IHC staining. More cells were stained in case group and the staining intensity was higher 
Correlations between $\mathrm{TNF} \alpha, \mathrm{NF}-\kappa \mathrm{B}$, and COX2 in preterm labor were evaluated. Expressions of $\mathrm{TNF} \alpha$ and $\mathrm{NF}-\kappa \mathrm{B}$ had weak correlation $(\mathrm{r}=0.385$; $\left.\mathrm{r}^{2}=0.148 ; \mathrm{p}=0.036\right), \mathrm{NF}-\kappa \mathrm{B}$ and COX-2 had no correlation $\left(\mathrm{r}=0.04 ; \mathrm{r}^{2}=0.0016 ; \mathrm{p}=0.982\right)$, and $\mathrm{TNF} \alpha$ and COX-2 had also no correlation $(\mathrm{r}=0.189$; $\left.\mathrm{r}^{2}=0.035 ; \mathrm{p}=0.315\right)$ in preterm labor.

Meanwhile, $r^{2}$ of TNF $\alpha$ and NF- $\kappa$ B was 0.148 indicating that expression of $\mathrm{TNF} \alpha$ has $14.8 \%$ contribution towards the expression of NF- $\kappa \mathrm{B}$. This was found to be statistically significant with $\mathrm{p}=0.036$. The correlation was not found to be significant between $\mathrm{NF}-\kappa \mathrm{B}$ and COX-2, implying that the influence of other factors toward the expression of COX-2 was higher than the effect of $\mathrm{NF}-\kappa \mathrm{B}$. Correlation between TNF $\alpha$ and COX-2 expressions was not found to be statistically significant. This suggests that the influence of TNF $\alpha$ is insignificant and other factors may be more influential on COX-2 expression.

\section{DISCUSSION}

The important factor for preterm labor related to inflammation (COX-2 and prostaglandin) is NF$\kappa \mathrm{B}$ which is activated by numbers of inflammatory mediators, including cytokines and lipopolysaccharide (LPS). TNF $\alpha$ increases cytoplasmic expression of IkB kinase (IKK) and phosphorylated $\operatorname{Ik} \beta-\alpha$ and NF- $\kappa B$ nuclear proteins p50 and p65. This is associated with a concurrent increase in COX-2 protein, and IL-6 and prostaglandin F2 $\alpha$ release from JEG-3 cells. ${ }^{8,10}$ Leukocyte count was higher in case group of which of approximately $30 \%$ higher than control. Leukocyte plays important role as marker of infection and inflammation. This proved that infection was related with preterm labor. This is supported by previous studies that state infection as the most common cause of preterm labor responsible for $50-80 \%$ of cases. ${ }^{4,5}$

Our study found higher TNF $\alpha$ expression in the preterm labor group. This may be related to the increase of mean of leukocyte count. It has been widely accepted that infection, especially chorioamnionitis, is the most common cause of preterm labor. Such infection will trigger the production of TNF $\alpha$ cytokines, explaining the elevated TNF $\alpha$ in the preterm group. Other factors such as placental stress and oxidative stress may trigger monocytes and neutrophils in producing TNFa. Longterm production of low levels of TNF $\alpha$ will lead to tissue remodeling and be as a factor in angiogenesis. However, excessive production will lead to endothelial damage. ${ }^{11-13}$
Cyclooxygenase (COX) activity is increased in human amnion in term and idiopathic preterm labor. It contribute to the generation of uterotonic prostaglandins (PG) that are known to play role in the birth process of mammals. COX-2 expression and PGE2 production induced by TNF $\alpha .{ }^{14}$ The mean of NF- $\kappa \mathrm{B}$ expression was found to be significantly higher in the preterm group. High levels of NF$\kappa \mathrm{B}$ could be due to other than inflammation, such as cancer, neurodegenerative disorders, diabetes, asthma, excessive apoptosis, Alzheimer's disease, Crohn's disease and ulcerative colitis. ${ }^{15,16}$ In pregnancy, stress will lead to glutamic acid release

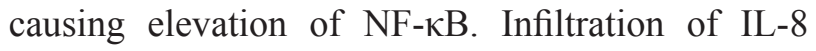
into the membranes, decidua, and cervix as well as pressure on the cervix also causes $\mathrm{NF}-\kappa \mathrm{B}$ expression increased. ${ }^{8}$ Surfactants produced from fetal lung, will increase migration of amniotic macrophage into the uterine wall, leading to NF- $\kappa \mathrm{B}$ expression. ${ }^{17}$ Our study found mean COX-2 level was higher in preterm labor compared to normal labor. Besides $\mathrm{TNF} \alpha$, elevation of COX-2 expression is also influenced by fetal conditions.

High cortisol level due to fetal distress or oxidative stress will lead to an increase of COX-2, which subsequently elevates prostaglandin levels initiating the labor process. Furthermore, low progesterone concentration in term labor will also trigger cortisol production. As observed in our study, COX-2 expression was elevated in normal labor but the elevation is more prominent in preterm labor where higher stress is the triggering factor. ${ }^{18}$

A significant positive correlation was found between the expressions of TNF- $\alpha$ and NF- $\kappa \mathrm{B}$. No significant correlation was found between $\mathrm{NF}-\kappa \mathrm{B}$ and $\mathrm{COX}-2$ expression in preterm labor. Although IHC staining for COX-2 appeared to be intensified in preterm labor, it seems that expression of NF- $\kappa \mathrm{B}$ did not have much influence on COX-2 expression. Furthermore, there was no correlation between TNF $\alpha$ and COX2 expressions. COX-2 activation pathway without activation of $\mathrm{NF}-\kappa \mathrm{B}$ needs to be studied since our study did not reveal correlation between expressions of $\mathrm{NF}-\kappa \mathrm{B}$ and $\mathrm{COX}-2$ in preterm labor.

Pathway activation of $\mathrm{NF}-\kappa \mathrm{B}$ in the process of angiogenesis, proliferation and invasion and metastasis of cancer is similar as in preterm labor that starts from an increase in $\mathrm{TNF} \alpha$. In the process of cell proliferation, increase of COX-2 will increase in prostaglandin, whereas in preterm labor, NF- 
$\kappa \mathrm{B}$ activation would lead to an increase of COX-2 and prostaglandin. The high prostaglandin causes uterine contractions, cervical dilation and rupture of the membranes. ${ }^{8,14,16}$ By inhibiting the increase of $\mathrm{TNF} \alpha$, activation of NF- $\mathrm{BB}$, and increase of COX-2, preterm labor may be prevented. Salicyclic acid and glucocorticoid may inhibit the activation of NF- $\mathrm{KB}$ or COX-2. ${ }^{19,20}$

Folic acid (FA) supplementation during pregnancy reduces the risk of neural tube defects, but it may be used to prevent preterm labor and intrauterine growth restriction (IUGR). FA significantly reduced interleukin- 6 and keratinocyte-derived cytokine in the amniotic fluid of LPS-treated mice. Maternal FA supplementation during pregnancy may protect against LPS-induced preterm delivery, fetal death, and IUGR through anti-inflammatory effects. ${ }^{21}$ It was said that the use of FA may also suppress the increase of NF-kB. Hence, it may suppress the increase of prostaglandins and prevent preterm labor. ${ }^{21}$

In conclusion, we found that expressions of TNF- $\alpha$, $\mathrm{NF}-\kappa \mathrm{B}$, and COX-2 were significantly higher in preterm labor compared to term labor. Positive correlation between the TNF- $\alpha$ and NF- $\mathrm{kB}$ was also identified, although no further correlation was found towards the COX-2 expression. Further study need to be performed to know other factors or pathways contributing preterm labor, especially susceptible genes that may increase NF- $\mathrm{KB}$ and COX-2 in women at risk for preterm labor.

\section{Conflict of interest}

The authors affirm no conflict of interest in this study.

\section{REFERENCES}

1. Blencowe H, Cousens S, Oestergaard MZ, Chou D, Moller $\mathrm{AB}$, Narwal R, et al. National, regional, and worldwide estimates of preterm birth rates in the year 2010 with time trends since 1990 for selected countries: a systematic analysis and implications. Lancet. 2012;379(9832):2162-72.

2. Usman I, Effendi JS. Tinjauan kasus persalinan premature di RSHS tahun 1998-2000. In, PIT POGI XII. Palembang; 2001. Indonesian.

3. WHO. WHO: recommended definitions, terminology and format for statistical tables related to the perinatal period and use of a new certificate for cause of perinatal deaths. Modifications recommended by FIGO as amended October 14, 1976. Acta Obstet Gynecol Scand. 1977;56(3):247-53.

4. Goldenberg RL, Culhane JF, Iams JD, Romero R. Epidemiology and causes of preterm birth. Lancet. 2008;371(9606):75-84.
5. Koucký M, Germanová A, Hájek Z, Pařízek A, Kalousová M, Kopecký P. Pathophysiology of preterm labour. Prague Med Rep. 2009;110(1):13-24.

6. Simmons LE, Rubens CE, Darmstadt GL, Gravett MG. Preventing preterm birth and neonatal mortality: exploring the epidemiology, causes and interventions. Semin Perinatol. 2010;34(6):408-15.

7. Collins JJ, Usip S, McCarson KE, Papka RE. Sensory nerves and neuropeptides in uterine cervical ripening. Peptides. 2002;23(1):167-83.

8. Lindström TM, Bennett PR. The role of nuclear factor kappa B in human labour. Reproduction. 2005;130(5):569-81.

9. Palliser HK, Hirst JJ, Ooi GT, Rice GE, Dellios NL, Escalona RM, et al. Prostaglandin E and F receptor expressionand myometrial sensitivity at labor onset in the sheep. Biol Reprod. 2005;72(4):937-43.

10. Lappas M, Yee K, Permezel M, Rice GE. Lipopolysaccharide and TNF- $\alpha$ activate the nuclear factor kappa B pathway in the human placental JEG-3 cells. Placenta. 2006; 27(6-7):568-75.

11. Burdon C, Mann C, Cindrova-Davies T, Ferguson-Smith $\mathrm{AC}$, Burton GJ. Oxidative stress and the induction of cyclooxygenase enzymes and apoptosis in the murine placenta. Placenta. 2007;28(7):724-33.

12. Cindrova-Davies T, Yung HW, Johns J, Spasic-Boskovic O, Korolchuk S, Jauniaux E, et al. Oxidative stress, gene expression, and protein changes induced in the human placenta during labor. Am J Pathol. 2007;171(4):1168-79.

13. Lockwood CJ. Stress-associated preterm delivery: the role of corticotrophin-releasing hormone. Am J Obstet Gynecol. 1999;180(1 Pt 3):S264-6.

14. Ackerman WE 4th, Zhang XL, Rovin BH, Kniss DA. Modulation of cytokine-induced cyclooxygenase 2 expression by PPARG ligands through NF kappa B signal disruption in human WISH and amnion cells. Biol Reprod. 2005;73(3):527-35.

15. Christman JW, Sadikot RT, Blackwell TS. The role of nuclear factor kappa-B in lung disease. Chest. 2000;117(5):1482-7.

16. Aggarwal BB, Shishodia S, Sandur SK, Pandey MK, Sethi G. Inflammation and cancer: how hot is the link? Biochem Pharmacol. 2006;72(11):1605-21.

17. Yamamoto Y, Gaynor RB. Potential therapeutic inhibition of NF- $\mathrm{KB}$ pathway in the treatment of inflammation and cancer. J Clin Invest. 2001;107(2):135-42.

18. Condon JC, Hardy DB, Kovaric K, Mendelson CR. Upregulation of the progesterone receptor (PR)-C isoform in laboring myometrium by activation of nuclear factor-kappaB may contribute to the onset of labor through inhibition of PR function. Mol Endocrinol. 2006;20(4):764-75.

19. Chen YH, Zhao M, Chen X, Zhang Y, Wang H, Huang $\mathrm{YY}$, et al. Zinc supplementation during pregnancy protects against lipopolysaccharide-induced fetal growth restriction and demise through its anti-inflammatory effect. J Immunol. 2012;189(1):454-63.

20. Orlando RA, Gonzales AM, Hunsaker LA, Franco CR, Royer RE, Vander Jagt DL, et al. Inhibition of nuclear factor $\mathrm{\kappa B}$ activation and cyclooxygenase-2 expression by aqueous extracts of Hispanic medicinal herbs. J Med Food. 2010;13(4):888-95.

21. Zhao M, Chen YH, Dong XT, Zhou J, Chen X, Wang H, et al. Folic acid protects against lipopolysaccharide-induced preterm delivery and intrauterine growth restriction through its anti-inflammatory effect in mice. PLoS ONE. 2013;8(12):e82713. 